\title{
AKTIVITAS EKSTRAK DAUN SIRSAK (Annona muricata L.) SECARA IN VIVO TERHADAP SCABIES PADA KAMBING KACANG (Capra hircus).
}

\author{
Risna Risyani, Abdul Wahid Jamaluddin, Muhammad Fadhlullah Mursalim \\ Program Studi Kedokteran Hewan, Fakultas Kedokteran, Universitas Hasanuddin \\ Email: risnarisyani.m@gmail.com; dullahmursalim@gmail.com
}

\begin{abstract}
The research was purposed to determine the activity of the leaf extract of soursop (Annona muricata L.) in dealing with scabies on Indonesian Native Kacang Goat (Capra hircus). There were 25 samples of scabies wounds used in this research. The samples were selected by examining the skin scrapings microscopically on goat which showed clinical symptoms of scabies to ensure mite infestion, Sarcoptes scabiei. Goat scabies are grouped into five treatment groups which consist of the positive control group, the negative control group, the group which was given the extract of soursop leaf of $10 \%$ concentration, the group which was given the extract of soursop leaf $20 \%$ concentration, and the group which was given the extract of soursop leaf extract $30 \%$ concentration. The treatment was given every day for seven days. The observation and the success assessment of scabies healing using a scoring method based on parameters of skin clinical changes consist of hair growth, scab, thickening, and skin folds. The conclusion of this research is the soursop leaf extract has an activity in healing scabies on Indonesian Native Kacang Goat (Capra hircus).
\end{abstract}

Key words: Ectoparasites, indonesian native kacang goat, scabies, soursop leaf extract

\section{PENDAHULUAN}

Ternak kambing mempunyai peranan sangat penting yaitu sebagai salah satu penghasil daging (protein hewani). Ternak kambing mampu beradaptasi pada kondisi daerah yang memiliki sumber pakan hijauan yang kurang baik, serta ternak kambing merupakan komponen peternakan rakyat yang cukup potensial sebagai penyedia daging. ${ }^{8}$ Dilihat dari populasi yang ada di nusantara ternak kambing menunjukan peningkatan yang positif, hal ini dibuktikan dengan keberadaan populasi yang meningkat rata-rata 4,75\% selama kurun waktu 2006 sampai dengan 2010. Di lain pihak permintaan konsumsi daging kambing juga meningkat rata-rata $27,4 \%$ selama tahun 2006 sampai dengan 2008. ${ }^{1}$

Penyakit parasitik merupakan salah satu faktor yang dapat menurunkan produktivitas ternak. Pada kambing penyakit parasitik yang sering ditemukan yakni scabies atau 
Aktivitas ekstrak daun sirsak (Annona muricata L.) secara In Vivo terhadap scabies pada kambing kacang (Capra hircus).

sering dikenal dengan penyakit kudis.

Scabies pada kambing disebabkan karena adanya infestasi tungau Sarcoptes scabiei var. caprae. Kambing yang menderita scabies memperlihatkan gejala gatal-gatal pada kulit, kemudian kulit akan melepuh terutama di daerah muka dan punggung, akhirnya cepat meluas ke seluruh tubuh. ${ }^{6}$

Sarcoptes scabiei mengalami siklus hidup mulai dari telur, larva, nimfa kemudian menjadi jantan dewasa dan betina dewasa muda dan matang kelamin. ${ }^{14}$ Penularan scabies terutama terjadi secara kontak langsung antar ternak sakit dan ternak sehat, baik antara hewan piaraan maupun antara hewan piaraan dan hewan liar. ${ }^{10}$

Tungau Sarcoptes mengisap cairan limfa dengan jalan melakukan perobekan lapisan epidermis, dan memakan sel-sel jaringan epidermis muda. Hal ini menyebabkan timbulnya rasa gatal yang terus menerus, sebagai akibatnya penderita akan menggosok-gosokkan tubuhnya sehingga mengakibatkan luka, yang pada akhirnya memperburuk kondisi tubuh penderita. Pada awalnya kulit mengalami erithema, kemudian berlanjut berbentuk papula, vesikula dan akhirnya terjadi peradangan yang diikuti oleh pembentukan eksudat. Eksudat mengendap pada permukaan kulit sehingga terbentuk keropeng/kerak. Proses selanjutnya, akan terjadi keratinisasi dan proliferasi yang berlebihan dari jaringan ikat sehingga menyebabkan bertambah tebalnya kulit serta terjadi pengeriputan. Selanjutnya akan diikuti oleh kerontokan bulu yang dapat terjadi pada seluruh permukaan tubuh. ${ }^{5}$

Pengendalian parasit ini dapat dilakukan dengan berbagai macam cara seperti penyemprotan ataupun dengan penyuntikan akarisida komersial. Akan tetapi mahalnya harga dan susahnya mendapatkan obat ini di desa-desa yang jauh dari perkotaan membuat obat tradisional menjadi alternatif bagi peternak kecil. ${ }^{2}$ Obat tradisional untuk hewan sering digunakan oleh peternak umumnya berasal dari tumbuhan asli Indonesia. ${ }^{13}$

Salah satu tumbuhan yang digunakan sebagai obat-obatan tradisional adalah tumbuhan sirsak (Annona muricata L). Tumbuhan sirsak ini dapat digunakan sebagai obat untuk menyembuhkan berbagai penyakit, mulai dari penyakit yang ringan seperti gatal-gatal pada kulit sampai penyakit berat seperti tumor 
Aktivitas ekstrak daun sirsak (Annona muricata L.) secara In Vivo terhadap scabies pada kambing kacang (Capra hircus).

dan kanker. Bagian tumbuhan sirsak yang dapat dimanfaatkan sebagai obat adalah: buah, daun, akar, biji, bunga, dan kulit batang. ${ }^{4}$

Daun, kulit, dan biji sirsak dapat berperan sebagai insektisida, larvasida, repellent (penolak serangga), dan antifeedant (penghambat makan) dengan cara kerja sebagai racun kontak dan racun perut. $^{2}$

Pada daun sirsak, telah ditemukan 18 jenis annonaceous acetogenin dan telah terbukti secara in vitro bersifat sitotoksik. Bahan bioaktif ini terbukti memiliki sifat antibakteri, antijamur, antikanker, melawan berbagai parasite. ${ }^{17}$

Daun sirsak (A. muricata) memiliki kandungan senyawa acetogenin, antara lain asimin, bulatacin, dan squamosin. Senyawa acetogenin dapat berfungsi sebagai anti feedant apabila dalam konsentrasi tinggi. Pada keadaan ini, hama tidak lagi bergairah melahap makanan yang disukainya. Tetapi pada suhu rendah, senyawa acetogenin dapat bersifat racun bagi hama sehingga menyebabkan kematian. ${ }^{10}$

\section{METODE PENELITIAN}

\section{Waktu dan Tempat}

Penelitian ini berlangsung pada bulan Oktober 2016. Pembuatan ekstrak daun sirsak dan konsentrasi ekstrak daun sirsak dilakukan di Laboratorium Biofarmaka PKP Universitas Hasanuddin. Untuk pemeriksaan sampel kerokan kulit kambing Kacang dilakukan di Dinas Peternakan dan Perikanan Kabupaten Soppeng dan penelitian dilakukan di Peternakan masyarakat di Kabupaten Soppeng.

\section{Alat dan Bahan}

Alat penelitian yang digunakan antara lain: sonikator, rotary evaporator, wadah (toples), pisau, blender, ayakan, herbs dryer, gelas ukur, sudip atau spatula, wadah porselen, timbangan, handskun, blade, botol vial, pipet tetes, mikroskop, object glass, cover glass, botol spray, dan kamera. Bahan penelitian yang digunakan antara lain: daun sirsak, etanol 70\%, Natrium Carboxymethyle Cellulose ( $\mathrm{NaCMC})$, aquades, Sulfadex sebagai bahan kelompok kontrol positif dan larutan $\mathrm{KOH} 10 \%$.

\section{Sampel yang digunakan}

Populasi hewan yang akan digunakan dalam penelitian ini adalah kambing kacang yang memiliki gejala klinis scabies, luas permukaan luka yang relatif sama, dan positif terinfestasi tungau sarcoptes scabiei. Sampel yang digunakan berjumlah 25 sampel yang kemudian dibagi dalam 
Aktivitas ekstrak daun sirsak (Annona muricata L.) secara In Vivo terhadap scabies pada kambing kacang (Capra hircus).

lima kelompok perlakuan yaitu 1 kelompok kontrol negatif, 1 kelompok kontrol postif dan 3 kelompok perlakuan. Pembeda ketiga kelompok perlakuan ini adalah konsentrasi ekstrak daun sirsak sebesar 10\%, 20\% dan $30 \%$.

\section{Prosedur Penelitian}

\section{Persiapan Sampel}

Sampel yang digunakan dalam penelitian ini yakni kambing Kacang yang menunjukkan gejala klinis scabies, memiliki permukaan luka scabies yang relatif sama serta positif scabies melalui pemeriksaan laboratorium.

Pemeriksaan laboratorium dilakukan dengan pemeriksaan kerokan kulit pada luka kambing Kacang yang menunjukkan gejala klinis scabies. Kerokan dilakukan sampai berdarah menggunakan blade kemudian dimasukkan ke dalam botol vial yang berisi $\mathrm{KOH} 10 \%$ yang selanjutnya diperiksa secara mikroskopis. Sampel yang diperoleh kemudian ditetes pada glass object dengan menggunakan pipet tetes kemudian ditutup dengan cover glass. Setelah itu, sampel diamati di bawah mikroskop pada pembesaran 100X. Apabila dalam sampel ditemukan tungau sarcoptes scabiei maka kambing Kacang tersebut dinyatakan positif scabies.

\section{Pembuatan Ekstrak Daun Sirsak ${ }^{15}$}

Sampel daun sirsak yang digunakan berasal dari Kabupaten Soppeng. Daun sirsak kemudian dibersihkan lalu dikeringkan dengan menggunakan herbs dryer pada suhu 45-55ㄷ. Selanjutnya dihaluskan dengan blender dan diayak dengan ayakan tepung sehinggga diperoleh simplisia daun sirsak. Pembuatan ekstrak daun sirsak ini menggunakan metode sonikasi dengan menggunakan pelarut etanol $70 \%$. Simplisia daun sirsak dimasukkan dalam wadah, perbandingan simplisia dengan pelarut etanol yakni 1:5 (b/v). Simplisia yang telah dicampur dengan pelarut kemudian dimasukkan ke dalam sonikator pada frekuensi $50 \mathrm{kHz}$ selama 1 jam. Hasil yang diperoleh kemudian disaring dan ditampung dalam wadah yang kemudian dipekatkan menggunakan rotary evaporator pada suhu $49^{\circ} \mathrm{C}$, kecepatan $20 \mathrm{rpm}$, dan tekanan 176 mBar sampai diperoleh ekstrak kental.

\section{Pembuatan Konsentrasi Ekstrak Daun Sirsak}

Sediaan ekstrak daun sirsak yang akan dibuat pada penelitian ini memiliki konsentrasi eksrak daun sirsak yang berbeda-beda yaitu $10 \%$, $20 \%$ dan 30\%. Proses pembuatan konsentrasi ekstrak daun sirsak 
Aktivitas ekstrak daun sirsak (Annona muricata L.) secara In Vivo terhadap scabies pada kambing kacang (Capra hircus).

menggunakan pensuspensi NaCMC $0,5 \%$. Dalam pembuatan konsentrasi ekstrak daun sirsak, hal pertama yang dilakukan yakni membuat pensuspensi NaCMC $\quad 0,5 \%$ yakni dengan menimbang $\mathrm{NaCMC}$ sebanyak 0,5 gram yang kemudian ditambahkan aquades hingga $100 \mathrm{ml}$. Selanjutnya pembuatan konsentrasi ekstrak daun sirsak 10\%, 20\% dan 30\%. Untuk pembuatan konsentrasi ekstrak daun sirsak $10 \%$ digunakan ekstrak kental daun sirsak 2 gram, 4 gram untuk konsentrasi ekstrak daun sirsak 20\% dan 6 gram untuk konsentrasi ekstrak daun sirsak $30 \%$. Kemudian dicampurkan dengan pensuspensi NaCMC $0,5 \%$ hingga masing-masing mencapai $20 \mathrm{ml}$. Kemudian diaduk hingga tercampur (homogen) lalu tiap konsentrasi dimasukkan dalam botol spray.

\section{Pemberian Obat Dan Ekstrak Daun} Sirsak Terhadap Luka Scabies Pada Kambing Kacang

Dalam pemberian obat dan ekstrak daun sirsak, sampel dibagi dalam 5 kelompok perlakuan. Satu kelompok untuk kontrol negatif dengan pemberian pensuspensi $\mathrm{NaCMC} 0,5 \%$, satu kelompok untuk kontrol positif dengan pemberian sulfadex, dan tiga kelompok untuk pemberian ekstrak daun sirsak masing-masing untuk konsentrasi 10\%, 20\% dan 30\%. Pemberian perlakuan dilakukan dengan cara disemprotkan secara merata pada seluruh permukaan luka scabies 1 kali sehari selama 7 hari.

\section{Pengamatan Pada Luka ${ }^{12}$}

Pengamatan pada luka dilakukan setelah 7 hari pemberian perlakuan dengan mengamati tandatanda kesembuhan dengan melihat perubahan kulit dan indikasi perbaikan jaringan dengan tumbuhnya rambut. Pengamatan dan penilaian terhadap kesembuhan luka dilakukan dengan menggunakan metode scoring pada tiap parameter kesembuhan luka scabies. Parameter keberhasilan kesembuhan luka scabies dilihat dari perubahan klinis kulit yang terinfestasi yang terdiri dari pertumbuhan rambut, keropeng dan penebalan serta lipatan kulit.

\section{Analisis Data \\ Pendataan dilakukan menggunakan metode scoring.}


Aktivitas ekstrak daun sirsak (Annona muricata L.) secara In Vivo terhadap scabies pada kambing kacang (Capra hircus).

\section{HASIL PENELITIAN}

Tabel 1. Scoring derajat kesembuhan luka scabies

\begin{tabular}{|c|c|c|c|}
\hline Skor & Pertumbuhan Rambut & Keropeng & Penebalan dan Lipatan Kulit \\
\hline 0 & Tidak ada pertumbuhan rambut & $\begin{array}{l}\text { Seluruh permukaan luka } \\
\text { ditutupi keropeng }\end{array}$ & $\begin{array}{l}\text { Penebalan dan lipatan kulit } \\
\text { tampak di seluruh permukaan } \\
\text { luka }\end{array}$ \\
\hline 1 & $\begin{array}{l}\text { Pertumbuhan rambut }<2 / 3 \mathrm{di} \\
\text { permukaan luka }\end{array}$ & $\begin{array}{c}>2 / 3 \text { permukaan luka masih } \\
\text { terdapat keropeng }\end{array}$ & $\begin{array}{c}>2 / 3 \text { permukaan luka masih } \\
\text { terdapat penebalan dan lipatan } \\
\text { kulit }\end{array}$ \\
\hline 2 & $\begin{array}{l}\text { Pertumbuhan rambut }>2 / 3 \mathrm{di} \\
\text { permukaan luka }\end{array}$ & $\begin{array}{l}<2 / 3 \text { permukaan luka masih } \\
\text { terdapat keropeng hingga } \\
\text { bersih dari keropeng }\end{array}$ & $\begin{array}{c}<2 / 3 \text { permukaan luka yang } \\
\text { mengalami penebalan dan } \\
\text { lipatan kulit hingga tidak ada } \\
\text { penebalan dan lipatan kulit }\end{array}$ \\
\hline
\end{tabular}

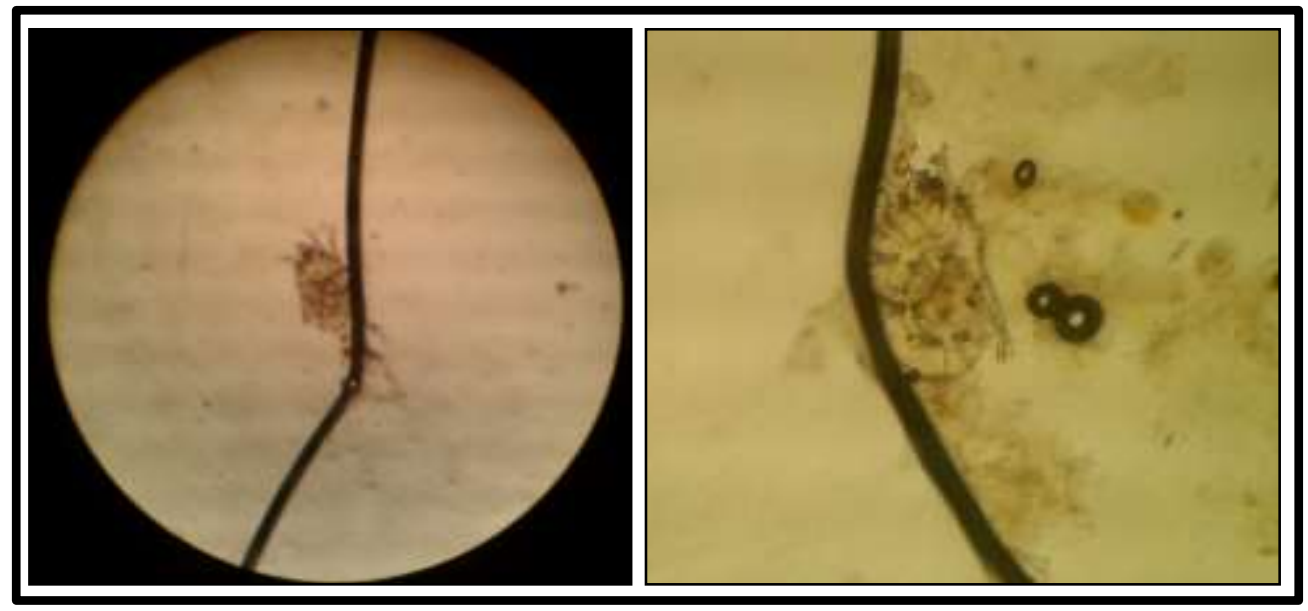

Gambar 1. Hasil pemeriksaan mikroskopis kerokan kulit kambing dengan pembesaran 100X.

Tabel 2. Persentase derajat perubahan luka pada parameter pertumbuhan rambut

\begin{tabular}{cccccc}
\hline \multirow{2}{*}{$\begin{array}{c}\text { Kelompok } \\
\text { Perlakuan }\end{array}$} & Jumlah & \multicolumn{2}{c}{ Skor Pertumbuhan Rambut (\%) } & \multirow{2}{*}{ Total } \\
\cline { 3 - 5 } & Sampel & $\mathbf{0}$ & $\mathbf{1}$ & $\mathbf{2}$ & \\
\hline $\mathrm{K}(+)$ & 5 & $0(0 \%)$ & $0(0 \%)$ & $5(100 \%)$ & $5(100 \%)$ \\
$\mathrm{K}(-)$ & 5 & $2(40 \%)$ & $3(60 \%)$ & $0(0 \%)$ & $5(100 \%)$ \\
EDS1 & 5 & $0(0 \%)$ & $3(60 \%)$ & $2(40 \%)$ & $5(100 \%)$ \\
EDS2 & 5 & $0(0 \%)$ & $2(40 \%)$ & $3(60 \%)$ & $5(100 \%)$ \\
EDS3 & 5 & $0(0 \%)$ & $0(0 \%)$ & $5(100 \%)$ & $5(100 \%)$ \\
\hline
\end{tabular}

Keterangan: K (+): Kontrol Positif; K(-): Kontrol Negatif; EDS1: Ekstrak Daun Sirsak Konsentrasi 10\%; EDS2: Ekstrak Daun Sirsak Konsentrasi 20\%; EDS3: Ekstrak Daun Sirsak Konsentrasi 30\%. 
Aktivitas ekstrak daun sirsak (Annona muricata L.) secara In Vivo terhadap scabies pada kambing kacang (Capra hircus).

Tabel 3. Persentase derajat perubahan luka pada parameter keropeng

\begin{tabular}{cccccc}
\hline Kelompok & Jumlah & \multicolumn{3}{c}{ Skor keropeng (\%) } & \multirow{2}{*}{ Total } \\
\cline { 3 - 5 } Perlakuan & Sampel & $\mathbf{0}$ & $\mathbf{1}$ & $\mathbf{2}$ & \\
\hline $\mathrm{K}(+)$ & 5 & $0(0 \%)$ & $1(20 \%)$ & $4(80 \%)$ & $5(100 \%)$ \\
$\mathrm{K}(-)$ & 5 & $5(100 \%)$ & $0(0 \%)$ & $0(0 \%)$ & $5(100 \%)$ \\
EDS1 & 5 & $0(0 \%)$ & $1(20 \%)$ & $4(80 \%)$ & $5(100 \%)$ \\
EDS2 & 5 & $0(0 \%)$ & $1(20 \%)$ & $4(80 \%)$ & $5(100 \%)$ \\
EDS3 & 5 & $0(0 \%)$ & $1(20 \%)$ & $4(80 \%)$ & $5(100 \%)$ \\
\hline
\end{tabular}

Tabel 4. Persentase derajat perubahan luka pada parameter penebalan dan lipatan kulit.

\begin{tabular}{cccccc}
\hline \multirow{2}{*}{$\begin{array}{c}\text { Kelompok } \\
\text { Perlakuan }\end{array}$} & $\begin{array}{c}\text { Jumlah } \\
\text { Sampel }\end{array}$ & \multicolumn{2}{c}{ Skor Penebalan dan Lipatan Kulit } & \multirow{2}{*}{ Total } \\
\cline { 3 - 5 } & & $\mathbf{0}$ & $\mathbf{0})$ & $\mathbf{1}$ & $\mathbf{2}$ \\
\hline $\mathrm{K}(+)$ & 5 & $0(0 \%)$ & $5(100 \%)$ & $0(0 \%)$ & $5(100 \%)$ \\
$\mathrm{K}(-)$ & 5 & $5(100 \%)$ & $0(100 \%)$ & $0(0 \%)$ & $5(100 \%)$ \\
EDS1 & 5 & $0(0 \%)$ & $1(20 \%)$ & $4(80 \%)$ & $5(100 \%)$ \\
EDS2 & 5 & $0(0 \%)$ & $1(20 \%)$ & $4(80 \%)$ & $5(100 \%)$ \\
EDS3 & 5 & $0(0 \%)$ & $0(0 \%)$ & $5(100 \%)$ & $5(100 \%)$ \\
\hline
\end{tabular}

\section{PEMBAHASAN}

Pemilihan sampel dilakukan dengan melihat adanya gejala klinis scabies dilanjutkan dengan pemeriksaan mikroskopis kerokan kulit dari bagian tubuh kambing Kacang yang menunjukkan gejala klinis scabies. Pemeriksaan ini dilakukan untuk memastikan adanya infestasi dari tungau Sarcoptes scabiei yang merupakan penyebab scabies pada kambing kacang. Sampel yang digunakan sebanyak 25 sampel.

Pengobatan pada sampel dilakukan dengan cara spray, yakni dengan disemprotkan langsung ke seluruh permukaan luka secara merata. Pengobatan dilakukan setiap hari selama tujuh hari dan kemudian dilakukan pengamatan terhadap kesembuhan luka setelah tujuh hari pengobatan. Dari hasil perlakuan menunjukkan Ekstrak daun sirsak yang diberikan pada kelompok perlakuan menunjukkan dampak positif terhadap luka scabies pada kambing Kacang dibandingkan dengan kelompok kontrol negatif.

Dari tabel 2 diatas terlihat persentase scoring derajat kesembuhan luka scabies kambing Kacang pada parameter pertumbuhan rambut pada setiap kelompok perlakuan. Data diatas menunjukkan semakin tinggi derajat scoring, maka semakin baik tingkat pertumbuhan 
Aktivitas ekstrak daun sirsak (Annona muricata L.) secara In Vivo terhadap scabies pada kambing kacang (Capra hircus).

rambut pada luka scabies. Apabila pada luka tidak terjadi pertumbuhan rambut diberikan skor 0 , skor 1 apabila terjadi pertumbuhan rambut $<2 / 3$ dari permukaan luka dan skor 2 apabila terjadi pertumbuhan rambut $>2 / 3$ dari permukaan luka. Persentase pertumbuhan rambut untuk kontrol positif sebesar $100 \%$ (skor 2), kontrol negatif sebesar $40 \%$ (skor 0), 60\% (skor 1) dan $0 \%$ (skor 2). EDS1 sebesar $60 \%$ (skor 1) dan 40\% (skor 2), EDS2 sebesar 40\% (skor 1) dan $60 \%$ (skor 2) dan EDS3 sebesar 100\% (skor 2). Berdasarkan penelitian yang dilakukan diperoleh hasil untuk proses kesembuhan luka pada parameter pertumbuhan rambut, kontrol positif dan kelompok EDS3 menunjukkan hasil yang lebih baik dibandingkan kelompok kontrol negatif, EDS1 dan EDS2.

Dari tabel 3 diatas terlihat
persentase
scoring
Kacang pada parameter keropeng pada setiap kelompok perlakuan. Sedangkan gambar 4.5 menunjukkan grafik scoring semua sampel pada tiap kelompok perlakuan pada parameter keropeng. Data diatas menunjukkan semakin tinggi derajat scoring, maka semakin baik tingkat kebersihan keropeng pada permukaan luka.
Apabila pada luka masih tertutupi oleh keropeng diberikan skor 0 , skor 1 apabila $>2 / 3$ dari permukaan luka masih terdapat keropeng dan skor 2 apabila $<2 / 3$ permukaan luka masih terdapat keropeng hingga bersih dari keropeng. Persentase kebersihan luka dari keropeng untuk kontrol positif sebesar 20\% (skor 1 ) dan $80 \%$ (skor 2), kontrol negatif sebesar $100 \%$ (skor 0), EDS1 sebesar 20\% (skor 1) dan $80 \%$ (skor 2), EDS2 sebesar 20\% (skor 1) dan $80 \%$ (skor 2) dan EDS3 sebesar 20\% (skor 1 ) dan $80 \%$ (skor 2). Berdasarkan penelitian yang dilakukan diperoleh hasil untuk proses kesembuhan luka pada parameter keropeng, kontrol positif dan kelompok pemberian ekstrak (EDS1, EDS2, dan EDS3) menunjukkan persentase kesembuhan yang sama.

Dari tabel 4 diatas terlihat persentase scoring derajat kesembuhan luka scabies kambing Kacang pada parameter penebalan dan lipatan kulit pada setiap kelompok perlakuan. Data diatas menunjukkan semakin tinggi derajat scoring, maka semakin baik perubahan tingkat penebalan dan lipatan kulit pada luka. Apabila pada seluruh permukaan luka masih tampak adanya penebalan dan lipatan kulit diberikan skor 0 , skor 1 apabila $>2 / 3$ permukaan luka masih 
Aktivitas ekstrak daun sirsak (Annona muricata L.) secara In Vivo terhadap scabies pada kambing kacang (Capra hircus).

terdapat penebalan dan lipatan kulit dan skor 2 apabila $<2 / 3$ permukaan luka yang mengalami penebalan dan lipatan kulit hingga tidak ada penebalan dan lipatan kulit. Persentase penebalan dan lipatan kulit untuk kontrol positif sebesar 100\% (skor 1), kontrol negatif sebesar $100 \%$ (skor 1), EDS1 sebesar 20\% (skor 1) dan $80 \%$ (skor 2), EDS2 sebesar $80 \%$ (skor 2) dan EDS3 sebesar 100\% (skor 2). Berdasarkan penelitian yang dilakukan diperoleh hasil untuk proses kesembuhan luka pada parameter penebalan dan lipatan kulit, kelompok perlakuan EDS3 menunjukkan hasil yang lebih baik.

Berdasarkan data persentase scoring kesembuhan luka pada tiap parameter kesembuhan luka scabies yang terdiri dari pertumbuhan rambut, keropeng serta penebalan dan lipatan kulit, maka diperoleh urutan hasil yang terbaik dari tiap parameter sebagai berikut:

1. Pertumbuhan Rambut: $\mathrm{K}(+)$ dan EDS3; EDS2; EDS1; K(-)

2. Keropeng: $\mathrm{K}(+)$, EDS3, EDS2 dan EDS1; K(-)

3. Penebalan dan Lipatan Kulit: EDS3; EDS2 dan EDS1; K(+); K(-)

Dari hasil tersebut menunjukkan pada parameter pertumbuhan rambut pemberian kontrol $(+)$ dan pemberian ekstrak daun sirsak konsentrasi 30\% menunjukkan persentase kesembuhan luka yang sama. Pada parameter keropeng pemberian kontrol (+), pemberian ekstrak daun sirsak konsentrasi $30 \%$, 20\% dan $10 \%$ menunjukkan persentase kesembuhan luka yang sama. Namun pada parameter penebalan dan lipatan kulit, pemberian ekstrak daun sirsak konsentrasi $\quad 30 \% \quad$ menunjukkan persentase kesembuhan luka yang lebih baik dibandingkan semua kelompok perlakuan. Data tersebut menunjukkan adanya aktivitas ekstrak daun sirsak dalam proses penyembuhan luka scabies pada kambing Kacang. Dimana pemberian ekstrak daun sirsak konsentrasi 30\% memiliki aktivitas penyembuhan luka yang hampir sama dengan pemberian kontrol positif.

Kemampuan daun sirsak dalam penyembuhan scabies disebabkan daun sirsak mengandung senyawa acetogenin, tannin, alkaloid, flavonoid dan steroida. ${ }^{11}$ Senyawa acetogenin berfungsi sebagai antifeedant terhadap ektoparasit. Dalam penyembuhan luka scabies, senyawa ini berperan dalam membunuh tungau sarcoptes scabiei.

Mekanisme kerja dari senyawa golongan acetogenin ini adalah melalui 
Aktivitas ekstrak daun sirsak (Annona muricata L.) secara In Vivo terhadap scabies pada kambing kacang (Capra hircus).

proses inhibisi respirasi (spesifik pada komplek NADH ubiquinon oxidoreductase). Proses inhibisi pada tungau Sarcoptes scabiei ini mengakibatkan terganggunya transfer elektron dari NADH menuju ubiquinone sehingga mengganggu proses respirasi seluler pada mitokondria secara keseluruhan. Akibat terganggunya proses respirasi ini maka proses pembentukan ATP tidak akan berjalan dengan benar sehingga organisme tidak akan bisa memperoleh energi yang cukup untuk memenuhi kebutuhan metabolismenya, dengan tidak terpenuhinya kebutuhan metabolisme akan menyebabkan kematian pada ektoparasit. ${ }^{7}$ Dengan adanya kematian terhadap tungau Sarcoptes scabiei, menyebabkan terjadinya penurunan infestasi tungau pada luka sehingga dapat menghambat atau menghentikan terjadinya perluasan luka (penyebaran infestasi tungau).

Dalam proses penyembuhan luka, alkaloid dan tannin berperan sebagai antimikrobial dan antijamur sehingga dapat mencegah terjadinya infeksi sekunder pada luka. Flavonoid dapat mengatur fungsi imun tubuh dan menghambat inflamasi, proliferasi dan angiogenesis. $^{9}$ Sedangkan peran senyawa steroid dalam menyembuhkan luka adalah meningkatkan deposisi kolagen, reepitelisasi, angiogenesis dan kontraksi luka pada fase proliferasi. ${ }^{3}$

\section{KESIMPULAN}

Ekstrak daun sirsak memiliki aktivitas dalam proses penyembuhan luka scabies pada kambing kacang. Ekstrak daun sirsak konsentrasi 30\% memberikan efek kesembuhan scabies yang lebih baik dibandingkan dengan ekstrak daun sirsak konsentrasi $10 \%$ dan $20 \%$.

\section{DAFTAR PUSTAKA}

1. Direktorat Jenderal Peternakan. Statistik Peternakan. Jakarta: BPS Pertanian Nasional, 2010.

2. Fahrimal, Yudha, Razali D, Adi C, Syauki I, Roslizawaty. Penggunaan Tepung Biji Sirsak (Annona muricata) Sebagai Akarisida Pada Sapi Dan Kambing. Jurnal Kedokteran Hewan. 2010;4(1).

3. John L, Burns MD, John S, Mancoll MD, Linda G, Ohillips MD. Impairements To Word Healing. Division of Plastic Surgery, University of Texas Medical Branch, 2003.

4. Malau, Ferdinan H. Isolasi Senyawa Flavonoida dari Kulit Batang Tumbuhan Sirsak (Annona muricata Linn) (Skripsi). Medan: USU, 2011.

5. Nayel NM and Abu-Samra MT. Experimental infection of the one humped camel (Camelus dromedaries) with Sarcoptes scabie var cameli and Sarcoptes 
Aktivitas ekstrak daun sirsak (Annona muricata L.) secara In Vivo terhadap scabies pada kambing kacang (Capra hircus).

scabie var ovis . Annals of Tropical Medicine and Parasitology. 1986; n80 :553-561.

6. Noach, Fredrik P. Fuzzy Expert System Analisa Tingkat Keparahan Penyakit Scabies Pada Kambing. Jurnal ELTEK. 2013;11(02):55-56.

7. Panagribuan, Margaretha, Pribadi TA, dan Indriyanti DR. Uji Ekstrak Daun Sirsak Terhadap Mortalitas Ektoparasit Benih Udang Windu Panaeys monodon. Unnes Journal of Life Science.2012.

8. Prawirodigjo SB. Utomo dan Herawati T. Produktivitas Induk dalam Usaha Kambing pada Kondisi Pedesaan. Ungaran: Balai Pengkaji Teknologi Pertanian, 2005.

9. Putra AAA. Pengaruh Ekstrak Etanol Daun Sirsak (Annona muricata) Terhadap Ekspresi Gen Capase 3 Pada Kkultur Sel Kanker Serviks Uteri HeLa. Bandung: Universitas Islam Bandung, 2012.

10. Septerina N. Pengaruh Ekstrak Daun Sirsak sebagai Insektisida Rasional Terhadap Pertumbuhan dan Hasil Tanaman Paprika Varietas Bell Boy. Malang: Universitas Muhammadiyah Malang, 2002.

11. Suranto A. Dahsyatnya Sirsak Tumpas Penyakit. Jakarta: Pustaka Bunda, 2011
12. Sweatmen GK. Mites and pentastomes. In " Parasitic Diseases of Wild Animals". (John W. Davis and Roy C. Anderson, eds.). USA: lowa State University Press Ames, 1971.

13. Tagboto $S$ and Townson $S$. Antiparasitic properties of medicinal plants and other naturally occurring products. Advance Parasitology. 2001;50:199-295.

14. Utami ASJ, Dinata AA dan Guntoro S. Pemanfaatan Asap Cair Sebagai Obat Scabies Pada Kambing. Seminar Nasional Teknologi Peternakan dan Veteriner. Denpasar: Balai Pengkajian Teknologi Pertanian Bali, 2008.

15. Vilkhu K, Mawson R, Simons L, Bates D. Application and Opportunities For Ultrasound Assisted Extraction In The Food Industry (A Review). Australia: Food innovation: Emerging Science, Technologies \& Application (FIESTA), 2006.

16. Williams RE, Hall RD, Broce AB, $P$. Scholl J. Livestock Entomology. New York: Jhon Wiley \& Son, 2000.

17.Zeng L, Ye Q, Oberlies NH, Shi G, Zhe-Ming, McLaughlin, Jerry L. Recent Advance in Annonaaneous Acetogenins. Natural Products Reports. 1996:276-306. 